\title{
Kadın İşçilerin Evlilik Nedeniyle İş Sözleşmesini Fesih Hakkı ve Sonuçları
}

\section{Selin UMUTLU $\mathbf{U}^{1}$}

\begin{tabular}{lcc}
\hline \multicolumn{1}{c}{ Geliş Tarihi/ Received } & Kabul Tarihi/ Accepted & Yayın Tarihi/ Published \\
19/02/2020 & $15 / 05 / 2020$ & $15 / 07 / 2020$ \\
\hline Citation/Atıf: Umutlu, S., (2020), Kadın İşçilerin Evlilik Nedeniyle İs Sözleşmesini Fesih Hakkl \\
ve Sonuçları, Atatürk Üniversitesi İktisadi ve İdari Bilimler Dergisi, 34(3): 877-894, DOI: \\
10.16951/atauniiibd.691178
\end{tabular}

Öz: Çalışma hayatına yönelik mevzuatta farklı türden çalışma ilişkileri yer almaktadır. İşçi ile işveren arasındaki çalışma ilişkisinin her zaman devamlılık arz etmesi beklenemez. Çalışma ilişkilerinin değişik şekillerde sona ermesi mümkündür. Bu noktada kadın işçilerin iş sözleşmelerini sona erdirebilmeleri için özel düzenleme sevk edilmiştir. Kadın işçilerin evlenmeleri halinde, sırf evlilik nedeniyle kendi iradeleri ile iş sözleşmelerini sona erdirmeleri mümkün kılınmıştır. Evlilik nedeniyle iş sözleşmesinin feshi yalnızca kadın işçiler için haklı neden sayılmıştır. Bu haliyle kadın işçilerin iş sözleşmelerini sona erdirdiklerinde kıdem tazminatı alacağına hak kazanacakları belirtilmiştir. $\mathrm{Bu}$ çalışmada kadın iş̧̧ilerin evlilik nedeniyle iş sözleşmelerini sona erdirebilme hakkı ve sonuçları üzerine değerlendirmeler yapılacaktır.

Anahtar Kelimeler: Kadın İşçi, Evlilik, İş Sözleşmesinin Feshi, Kıdem Tazminatı.

\section{The Right and Consequences of Termination of The Employment Contract of Female \\ Workers due to Marriage}

Abstract: Various labour relations are included in the legislation for working life. The working relationship between the worker and the employer cannot always be expected to be continuous. It is possible to end working relationships in different ways. Special regulation has been referred to allow women workers to terminate their employment contracts. In the case of marrying women workers, it was made possible for them to terminate their employment contracts on their own volition just because of the marriage. The termination of the marriage employment contract was deemed justified only for female workers. As such, it is stated that women workers will be entitled to severance pay when they terminate their employment contracts. In this study, the rights of women workers to terminate employment contracts due to marriage and their consequences will be evaluated.

Keywords: Female Worker, Married, Termination Of Employment Contract, Severance Pay.

\section{EXTENDED SUMMARY}

\section{Research Problem}

The aim of this study is to examine how women workers can terminate their employment contracts due to marriage and the rights and interests they have at this stage based on the principles of the law.

\footnotetext{
${ }^{I}$ Arş. Gör. Süleyman Demirel Üniversitesi, İktisadi ve İdari Bilimler Fakültesi, Çalışma Ekonomisi ve Endüstri İlişkiler Bölümü, https://orcid.org/0000-0002-0391-0179
} 


\section{Research Questions}

By what laws has this right to women workers been recognized?

What are the legal consequences of women workers marrying and wanting to leave work?

Is there any possibility of re-employment in the termination of the employment contract with marriage?

What sanctions can be imposed on women workers for termination of contract in a manner that is not in accordance with the law and the law?

What are the positive and negative aspects of this right granted to women workers by the law in force?

\section{Methodology}

The literature review showed that there are enough resources based on the rights and interests of women workers legally. However, a detailed investigation could not be reached into the fact that female workers only want to terminate their employment contracts because of 'marriage' and the possible consequences of this. In this study, the marriage of female workers under Labor Law and the termination of their contracts for this reason will be examined in detail.

\section{Results and Conclusions}

Women workers may wish to terminate their employment contracts and end their working lives after they have married due to social pressure, nonconsent of the spouse or no longer wanting to work. In this case, women workers can legally terminate their employment contract within one year of their marriage. For this reason, they will be able to have all the rights gained on the date of termination of the employment contract.

As well as the arrangements that facilitate the continuation of the working relationship for women workers can be found, there are also facilities for the termination of the working relationship. The most important of these is the right of women workers to terminate their employment contracts due to marriage and to receive severance pay based on these rights.

In the disadvantaged group of social policy, this right, which is aimed only at 'women', has positive as well as negative consequences. As it leads to gender inequality, a woman who wants to leave work may knowingly divorce her partner and seek to terminate the contract in the name of compensation. Also, employers may not want to employ female workers for these reasons. In light of such reasons, it may be insufficient for the legal regulation to remain in force as such..

\section{Giriş}

Fesih, iş sözleşmelerini sona erdirme yollarından birisidir. İş hayatını düzenleyen mevzuatta feshin tanımı açıkça belirtilmemiştir. Fesih; iş sözleşmesini geleceğe etki edecek şekilde sona erdirecek, ortadan kaldıracak yenilik doğurucu bir hak olarak tanımlanmaktadır (Esener, 1978: 223; Oğuzman, 1955: 41; Süzek, 2015: 529). Mevzuatta iş sözleşmesini fesih yoluyla sona erdirebilmek için çeşitli hal ve durumların ortaya çıkması gerekliliği 
belirtilmiştir. Bunlardan birisi de kadın işçilerin evlilik nedeniyle iş sözleşmelerini feshedebilecekleridir. Evlenen kadınların iş sözleşmelerini feshedilmelerine imkân tanınmış ve bu işçilerin kıdem tazminatı alabilmelerinin önü açılarak, kadın işçiler feshin kötü sonuçlarına karşı korumaya alınmışlardır. Kadın ișçilere yönelik çalıșma hayatında özel düzenlemelere rastlamak mümkündür. Bunlar 4857 sayılı İ.K. m. 72 de düzenlenen çalışma yasakları, m.74 de belirtilen analık izni, süt izni gibi durumlar olarak karşımıza çıkmaktadır. Kadın işçiler için iş ilişkisinin devamını kolaylaştırıcı düzenlemelere rastlanabildiği gibi, iş ilişkisinin sona ermesine yönelik kolaylıklar da bulunmaktadır. Bunların en önemlisi kadın işçilerin evlilik nedeniyle iş sözleşmelerini sona erdirebilme hakları ve bu haklarına istinaden kıdem tazminatı alabilmeleridir. İlk görünüş itibariyle kadın işçilerin evlilik nedeniyle iş sözleşmelerini haklı nedenle feshedebilecekleri düşünüldügünde ilgili düzenlemenin kadın işçilerin oldukça yararına olduğu sonucuna ulaşmak mümkün olacaktır. Her ne kadar kadın işçilere yönelik böyle bir hak tanınmış olsa da bunun altında, kadının toplumsal hayattaki yeri, kadının eş sıfatı gibi kavramlar irdelenmelidir. Evlilik nedeniyle iş sözleşmelerini feshedebilme hakkı gerçekten iyi niyetle verilmiş bir hak $\mathrm{m} ı$ yoksa kadınların çalışma hayatından çekilmelerinin önünü açmaya zemin hazırlayan bir düzenleme mi? (Centel, 2009: 5) Konuya sadece kadın işçilerin iş sözleşmelerini feshedebilme hakkı olarak yaklaşmak gerekse de, bu düzenleme işverenleri, bekâr kadın işçi işe alırken daha temkinli yaklaşmaya sevk edecektir. Bu haliyle de kadınların işgücü piyasasının dışına itilme, ya da iş gücü piyasasına hiç dâhil edilmeme tehlikesi bulunmaktadır. Yalnızca kadın işçilere tanınmış olan evlilik nedeniyle iş sözleşmesini feshedebilme imkânı, günümüz yürürlügündeki mevzuat çerçevesinde tekrar değerlendirilmesi gereken bir konu olarak karşımıza çıkmaktadır. Bu çalışma ile kadın işçilerin evlilik nedeniyle iş sözleşmelerini haklı nedenle fesih hakları ve sonuçları değerlendirilmeye çalışılacaktır.

\section{2.İş Sözleşmesinin Sona Erme Halleri}

\subsection{Fesih Dıș Sona Erme Halleri}

İş sözleşmeleri özel hukuk sözleşmeleri kapsamına girmektedir. Özel hukukta bir sözleşmenin sona erme halleri nasıl ise iş sözleşmeleri de aynı şekilde sona ermektedir. Bunlardan en tabii olanı kuşkusuz ölüm halidir. İşçi iş görme edimini şahsen ifaya mecbur olduğu için, işçinin ölümü halinde, ifayı gerçekleştirecek kişi hukuken kişiliğini kaybettiğinden iş sözleşmesi sona erecektir (Narmanlıoğlu, 2014: 335; Süzek, 2015: 534). Kiş̧iliği sona erdirecek hallerden birisi de Medeni Kanun'da gaiplik olarak belirtilmiştir. İşçinin gaipliğine karar verilmiş olması halinde de iş sözleşmesi kendiliğinden sona erecektir.

İş hukukunun özel hukuk niteliği ağır bastığı, taraflar arasında tam bir irade serbestisi ve eşitlik üzerine kurulu ilişkileri olduğu için, sözleşmeyi işçi ve 


\section{Kadın İş̧̧ilerin Evlilik Nedeniyle İ̧̧ Sözleşmesini Fesih Hakkı ve Sonuçları}

işveren tarafının anlaşarak her zaman sona erdirmeleri de mümkündür (Sümer, 2015: 87).

4857 sayılı İş Kanunu'nda belirli süreli iş sözleşmeleri düzenlenmiştir. Her ne kadar kanuni düzenleniş biçimi bakımından belirli süreli iş sözleşmeleri istisnai nitelikte olsa da bu türden iş sözleşmelerinin yapılması da mümkündür (Çelik ve Caniklioğlu, 2015: 304). Bu iş sözleşmelerinde sözleşmenin ne zaman sona ereceği sözleşmenin kuruluş aşamasından bellidir. Sözleşmenin sona ereceği süre, açıkça belirlenebileceği gibi bir işin sona ermesi ya da bir olgunun ortaya çıkmasına kadar iş ilişkisinin süreceği kararlaştırılabilir. Bu durumlar da belirlenen sürenin sona ermesi, belirli bir işin tamamlanması yahut bir olgunun ortaya çıkması ile iş sözleşmesi sona erecektir.

\subsection{Fesih Yoluyla Sona Erme Halleri}

Taraflar arasında bir kere iş ilişkisinin kurulması, bu ilişkinin ömür boyu süreceği anlamına gelmemektedir. İşçi yaşlanmış olup çalışma hayatından çekilmek isteyebilir, malul duruma düşebilir, yaptığı işi artık yapamayacak hale gelebilir, yeni bir işe girmek isteyebilir; işveren işçisinden memnun olmayabilir, iflas edebilir, bu gibi durumlarda iş sözleşmesinin sona erdirilmesi gerekecektir. İşte bu noktada iş sözleşmesinin feshi yoluna gidilmesi gerekmektedir.

4857 sayılı İş Kanunu'nda düzenlenen iki türlü fesih hakkı vardır. Bunlardan ilki m.17 de düzenlenen süreli fesih, ikincisi ise m.24 ve 25 de düzenlenen derhal fesih hakkıdır.

Süreli fesih hakkı kanunen hem işçi hem de işveren tarafına verilmiş bir haktır (Şakar, 2019: 90). Süreli fesih işçinin kıdemine göre işten ayrılma ya da çıkarılma isteğinin ne kadar süre önceden bildirmesi gerektiğini düzenleyen sürelerdir. Bu süreler işçinin yeni iş, işverenin de yeni iş̧̧i arayabilmesi için düzenlenmiştir (Mollamahmutoğlu vd., 2014: 912; Süzek, 2015: 547). Her ne kadar İ.K m.17 de süreli fesih hakkı tanınmış olsa da, bu yolla iş sözleşmesinin feshedilebilmesi için,İ.K. m.18 ile feshin geçerli nedene dayandırılması gerektiği belirtilmiştir. Bu noktada, iş güvencesi kapsamında olan ve olmayan işçiler için 'geçerli neden gösterme' ya da 'geçerli neden gösterme zorunluluğu' ayrılmaktadır (Günay, 2010: 155; Alp, 2003: 1). İlgili düzenleme uyarınca, iş sözleşmesini feshedebilmek için; işçinin yeterliliğinden veya davranışlarından ya da işletmenin, işyerinin veya işin gereklerinden kaynaklanan geçerli bir sebebin ortaya çıkması gerekmektedir. $\mathrm{Bu}$ düzenleme ile birlikte aynı maddenin devamında hangi hallerin iş sözleşmesini feshetmek için geçerli neden oluşturmayacağı da belirtilmiştir.

Derhal fesih hakkı İ.K. m.24 de işçi için, m.25 de işveren için düzenlenmiştir. Yani 24.cü maddede sayılan hallerin ortaya çıkması halinde işçi haklı nedenle iş sözleşmesini feshedebilirken, 25.ci madde de sayılan hallerin ortaya çıkması durumunda işveren, iş sözleşmesini haklı nedenle derhal fesih hakkına sahip olacaktır. İlgili maddeler karşılaştırıldığında sağlık sebepleri, ahlak ve iyi niyet kurallarına uymayan haller ve zorlayıcı sebepler nedeniyle işçiye de 
işverene de iş sözleşmesini feshetme hakkı tanınmıştır. Burada ki şartlar incelendiğinde iş sözleşmesinin derhal feshedilmesi gereken haller daha ağır durumlar olarak karşımıza çıkmaktadır (Kaplan, 1987: 130). Örneğin işçinin hırsızlık yapması ya da işverenin işçiye hakaret etmesi gibi durumlarda iş sözleşmesinin devam etmesini beklemek hakkaniyetli değildir. Bu gibi durumların ortaya çıkması halinde de sözleşmeyi sona erdirecek tarafın karşı tarafa sözleşmeyi feshetmek için bildirim süresi gibi bir süre vermesini beklemekte akılcı bir çözüm değildir. Bu hallerde sözleşmeyi sona erdirme hakkı olan tarafin kanuni ifade ile bu hakkını derhal kullanması gerekmektedir.

\section{Evlilik Nedeniyle İş Sözleşmesini Fesih Hakkı}

\subsection{Genel Olarak}

İş sözleşmesinin sona ermesinin en önemli sonucu, taraflar arasında maddi yönden hak ve borçların tam olarak ödenmesi gerekliliğidir. Bu konuda iş sözleşmesinin sona erme şekli ve nedenlerine göre, ihbar tazminatı, kıdem tazminatı, kötüniyet tazminatı gibi sonuçlar karşımıza çıkmaktadır.

Kıdem tazminatı konusu 1475 sayılı yürürlükten kaldırılan İş Kanunu'nda düzenlenmiştir. İlgili düzenleme incelendiğinde; “....kadının evlendiği tarihten itibaren bir yıl içerisinde kendi arzusu ile sona erdirmesi..." halinde kıdem tazminatına hak kazanacağı belirtilmiştir.

\subsection{Hakkın Düzenleniş Şekli ve Amacı}

1475 sayılı mülga İ.K. ilgili maddesi irdelendiğinde; evlilik nedeniyle iş sözleşmesini feshedilme hakkının yalnızca kadınlara verildiği görülmektedir. Anayasanın 50.ci maddesinde; küçüklerin, kadınların ve engellilerin çalışma şartları bakımından özel olarak korunacakları belirtilmiştir. Bu düzenleme doğrultusunda çalışma hayatında kadınlara yönelik özel koruyucu düzenlemelerin bulunması anayasanın bir gerekliliğidir. Çalışma hayatını, 'çalışma hayatına giriş, çalışma hayatının devam etmesi ve çalışma hayatının sona ermesi' şeklinde ayrı ayrı değerlendirmek gerekmektedir. 4857 sayılı İ.K. m.72 yer ve su altında kadınların çalıştırılmasını yasaklamıştır. Bu düzenleme çalışma hayatına girerken kadınlara yönelik koruyucu hüküm olarak değerlendirilebilir. Yine aynı kanunun 74.cü maddesinde kadınlara hamilelik ve analık halinde verilecek izinlerden bahsedilmektedir. İlgili düzenleme de çalışma hayatı devam erken kadınlara yönelik koruyucu hüküm olarak karşımıza çıkmaktadır. Son olarak çalışma hayatının sona erdirilebilmesi durumunda da mülga İ.K. uyarınca kadınların evlilik nedeniyle iş sözleşmesini haklı olarak feshedilecekleri düzenlenerek, kadınlara yönelik çalışma hayatının her anında ayrıcalık tanınması mümkün kılınmıştır.

Evlilik nedeniyle iş sözleşmesini haklı nedenle fesih hakkının yalnızca kadın işçilere tanındığı çeşitli Yargıtay Kararlarında da açıkça zikredilmektedir. "...Bu hak, sadece bayan eşe tanınmış...tır..." (Kazancı, Yargıtay 9. Hukuk Dairesi. E. 2007/18608 K. 2008/14177 T. 3.6.2008, Yargitay 9. Hukuk Dairesi. E. 2012/10999 K. 2014/16076 T. 20.5.2014). 


\section{Kadın İş̧̧ilerin Evlilik Nedeniyle İ̧̧ Sözleşmesini Fesih Hakkı ve Sonuçları}

Kanunda kadın işçilere evlilik nedeniyle iş sözleşmelerini feshedilme hakkı tanınırken, tek bir kısıtlama getirilmiş̧ir. $\mathrm{Bu}$ kısıtlama süre olarak karşımıza çıkmaktadır. Evlilik tarihinden itibaren bir yıl içinde iş sözleşmesini sona erdirmek gerekmektedir. Kanunun emredici hükmü uyarınca kadın iş̧̧inin evlendiği tarihten itibaren bu hakkını bir yıl içinde kullanması gerekmektedir. Evlenme tarihinin üzerinden bir y1llık süre geçtikten sonra kadın işçi kanunun vermiş olduğu bu yetkiden dolayı iş sözleşmesini haklı nedenle sona erdiremeyecektir. Sözleşmeyi sona erdirebilmesi için diğer nedenlerin olup olmadığını irdelemek gerekecektir. Oysa evlilik nedeniyle iş sözleşmesini haklı olarak sona erdirmek isteyen kadın işçi için başka herhangi bir şartın ortaya çıkması gerekmemektedir. Kısacası evlilik, başlı başına kadın işçi için iş sözleşmesini sona erdirirken haklı bir neden olarak görülmektedir.

Kadın işçinin iş sözleşmesini haklı nedenle sona erdirebilmesi için "evlilik" ifadesi zikredilmiştir. Evlilik şartları ve evliliğin resmen gerçekleşip gerçekleşmediği konusunda Türk Medeni Kanunu ve konu ile ilgili yönetmelik hükümleri dikkate alınmalıdır(Mollamahmutoğlu vd., 2014: 1122). Yani evliliğin yasal olarak gerçekleşmiş olması gerekmektedir. Resmi şekilde gerçekleştirilmeyen veya şekil ve usul şartları yerine getirilmemiş bir evlilik resmi evlilik olarak değerlendirilemeyeceği için, İş Kanununda yasal güvence altına alınmış olan kadın işçinin evlilik nedeniyle iş sözleşmesini sona erdirebilme imkânı bulunmayacaktır.

Kadın çalışanlara evlilik nedeniyle iş sözleşmelerini sona erdirebilme hakkının tanınmış olması, kadınların sosyal ve toplumsal yaşamda üstlenmiş oldukları diğer roller açısından da büyük önem arz etmektedir. Kadınlar, iş hayatında çalışan, evlilik hayatında eş, aile hayatında analık gibi roller üstlenmektedirler. Bekârken çalışma hayatına başlamış bir kadının ileride evlenmesi halinde eşine ve çocuklarına daha fazla zaman ayırmak istemesi olası bir durum olarak karşımıza çıkmaktadır. Bekârken çalışılabilecek bir iş, evlilik hayatında kadına yüklenen toplumsal değer ve yargılar nedeniyle, evlenen kadının işine devam etmesini beklemeyi mümkün kılmayabilir. İşte bu noktada sırf evlendiği için işi bırakma ya da iş değiştirmek isteyen kadın çalışanların hakları zayii olabilecektir. Bu düşünce ile kadınlara evlilik nedeniyle iş sözleşmelerini sona erdirebilme hakkı tanınmıştır. İlgili maddenin düzenleniş amacı Yargıtay'ın bir kararında da açıkça ifade edilmiştir. “...Evliliğin kadına yüklediği toplumsal sorumluluğun bir gereği olarak yasada belirtilen fesih hakkı tanınmıştır..." (Kazancı, Yargitay 9. Hukuk Dairesi. E. 2012/10999 K. 2014/16076 T. 20.5.2014)

1475 sayılı Kanun'da, kadın işçilere tanınan bu hak herhangi bir kısıtlama olmaksızın sağlanmıştır. Kadın işçinin kaç defa evlilik nedeniyle iş sözleşmesini sona erdirebileceği, evli kadının muvazaalı boşanarak aynı kişiyle yeniden evlenmesi durumunda bu hakkı kullanıp kullanamayacağı konularında kısıtlama yapılmadığı görülmektedir (Süzek, 2015: 763; Mollamahmutoğlu vd., 2014: 1123; Narmanlığlu, 2014: 578). Kısitlama yalnızca 'evlilik tarihinden itibaren 
bir yıl içinde hakkın kullanılması' yönünde yapılmıştır. Burada kadın çalışanların hakkı kötüye kullanıp kanunun arkasını dolanabilecekleri göz ardı edilmiştir. Özellikle çalıştığı işinde, işvereni, iş arkadaşları veya olumsuz çalışma koşullarından müzdarip olan ancak; iş sözleşmesini haklı nedenle sona erdirebilecek bir durum ile karşılaşmayan kadınlar, sırf evlilik nedeniyle iş sözleşmelerini haklı nedenle sona erdirebileceklerdir. $\mathrm{Bu}$ durumda, kâğıt üzerinde evlenip ve bu evlilik nedeniyle de iş sözleşmesini haklı nedenle sona erdirebileceklerdir. Asıl amacının evlilik olmadığı hallerde kanunu dolanmak için bu yola başvurulması durumunda kadın işçiye bu hakkın kullandırılıp, kullandırılmayacağı konusunda kanunda bir açıklık bulunmamaktadır. Evli kadının eşinden boşanıp, hemen boşandığı eşiyle yeniden evlenmesi ve evlilik nedeniyle iş sözleşmesini sona erdirmesi durumu hakkın kötüye kullanılması şeklinde değerlendirilebilir. Bu gibi durumlar ortaya çıkabileceği için kanunda evlilik nedeniyle iş sözleşmesini haklı nedenle feshetme imkânı tanınmış iken bunun şartlarının daha detaylı belirtilmesi gerekmektedir.

Kadın işçinin evlilik nedeniyle iş sözleşmesini sona erdirmesinden sonra başka bir işte çalışıp, çalışamayacağ 1 , çalışabilecekse aynı türden iş yapıp yapamayacağı ve ne kadar süre beklemesi gerektiği gibi konularda da kanunda bir sınırlama bulunmamaktadır. Anayasaya göre; "Herkes, dilediği alanda çalışma ve sözleşme hürriyetine sahiptir..." dolayısı ile anayasaya göre herkese çalışma ve sözleşme hürriyeti tanınmıştır. Buradan hareketle evlilik nedeniyle iş sözleşmesini sona erdiren bir kadının, çalışma hürriyetinin sona erdiği düşünülemez. Bu hakkını kullanan kadın çalışan başka bir işte çalışma ya da farklı türden bir iş sözleşmesi ile çalışma ihtiyacı duymuş olabilir. Tam süreli iş sözleşmesi ile çalışan bir kadının, evlendikten sonra kısmi süreli çalışma isteği doğmuş ya da evlilik nedeniyle yaşadığı, çalıştı̆̆ yerleşme durumu ortaya çıkmış olabilir. Dolayısı ile evlenen kadın iş̧̧iden ne pahasına olursa olsun işine devam etmesini beklemek hayatın olağan akışına uygun bir davranış olmayacaktır. Evlilik nedeniyle iş sözleşmesini sona erdiren kadının da bir daha hiç çalışma niyetinde olmadığını düşünmekte hakkaniyetli bir çözüm olmayacaktır. Bu konuda Yargıtay bir kararında; “...Kadın işçinin evlilik nedenine bağlı feshinin ardından kısa bir süre sonra yeniden çalışmasının gerekleri ortaya çıkmış olabilir.Hatta kadın işçi evlilik nedenine dayalı feshin ardından ara vermeksizin başka bir işyerinde çalışmaya başlayabilir ve bu durum evliliğin kadına yüklediği görevlerin yerine getirilmesi noktasında daha olumlu sonuçlar doğurabilir....'Kazanc1, Yargitay 9. Hukuk Dairesi E. 2012/10999 K. 2014/16076 T. 20.5.2014) sonucuna ulaşmıştır. Karardan da anlaşılacağ üzere kadın iş̧̧inin bu hakkını kullanmasının hemen ardından başka bir işte çalışmaya başlaması durumunda bile kadın iş̧̧inin hakkını kötüye kullandığı sonucuna ulaşılmamış, yeni işinde kadın işçinin evliliğin kadına yüklediği görevleri yerine getirme noktasında kolaylık sağlayabilme ihtimalini de göz önüne alarak, bu hakkın kullanılmasının hemen akabinde başka bir işe başlanmasına da olumlu 


\section{Kadın İşşilerin Evlilik Nedeniyle İş Sözleşmesini Fesih Hakkı ve Sonuçları}

görüş bildirmiştir. Benzer yönde kararlara rastlamak mümkündür (Kazanc1, Yargitay 22. Hukuk Dairesi E. 2017/10878 K. 2018/5005 T.27.2.2018).

Aynı işyerinde çalışan işçilerin evlenmesi halinde kadın işçinin evlilik nedeniyle iş sözleşmesini feshedilme imkânının olup olmadığı konusunda da kanunda bir açıklık bulunmamaktadır. Yargıtay bir kararında; aynı işyerinde çalışan işçilerin evlenmeleri halinde de kadın işçiye evlilik nedeniyle iş sözleşmesini haklı nedenle feshedilme imkânı tanınması gerektiğine kanaat getirmiştir (Kazancı, Yargitay 9. Hukuk Dairesi E. 2014/17600 K. 2015/30741 T. 2.11.2015).

\subsection{Hakkın Kullanılış Şekli}

Kadın işçilere verilen evlilik nedeniyle iş sözleşmesini fesih hakkı konusunda bu hakkın nasıl kullanılacağı hususunda mevzuatta bir açıklık bulunmamaktadır. 4857 sayılı İ.K. m.17; 'Belirsiz süreli iş sözleşmelerinin feshinden önce durumun diğer tarafa bildirilmesi gerekeceği' ni düzenlemiştir. Yine aynı kanunun m. 19; 'İ̧sverenin fesih bildirimini yazılı olarak yapması ve fesih sebebini açık ve kesin bir şekilde belirtmesi gerekmektedir' ifadesine yer verilmiştir. Ancak işçinin iş sözleşmesini feshederken nasıl bir yol izlemesi gerektiği belirtilmemiştir. İş hukukunda belirsiz süreli iş sözleşmelerinin esas olduğunu kabul edersek, kadın işçinin de evlilik nedeniyle iş sözleşmesini feshederken bu durumu diğer tarafa yani işverene bildirmesi gerekeceği sonucuna ulaşmak gerekecektir. Kadın işçinin bu haktan yararlanabilmesi için belirsiz süreli iş sözleşmesi ile çalışması da şart değildir (Mollamahmutoğlu vd., 2014: 1124).

Kadın iş̧̧inin evlilik nedeniyle iş sözleşmesini sona erdireceğini işverene bildirmesinin yazıl1, sözlü ya da resmi olarak hangi yöntemle yapılacağı hususunda da bir netlik yoktur. Kadın işçinin, işverene giderek ben evlendiğim için iş sözleşmemi feshediyorum diye sözlü beyanda bulunması halinde bu beyanın geçerli kabul edilip edilmeyeceği sorun yaratabilecektir. Yani kadın işçinin sözlü olarak bu hakkını işverene iletmesi feshin geçerli olabilmesi için yeterli olacak mıdır? Ya da bu hakkı kullanabilmek için yazılı yahut resmi bildirimde mi bulunmak gerekecektir? Bu durumlar, evlilik nedeniyle fesih hakkının kullanılması için geçerlilik şartı mı yoksa ispat şartı olarak mı yazılı1ık kuralını aramak gerekecektir? İşte bunca sorunlu durumun ortaya çıkabilme ihtimaline karşı kadın işçilerin bu hakkını nasıl kullanması gerektiğinin mevzuatta açıkça belirtilmemiş olması, kadın işçiler için bu hakkı kullanırken titiz davranmaları gerekliliğine aksi halde hakkını kullanmak yani geçerli fesihte bulunmak isterken, kıdem tazminatı başta olmak üzere birçok alacağı noktasında hak kaybına neden olabilecektir.

4857 sayılı İ.K.19'da işveren tarafindan yapılacak feshin yazılı olarak yapılması gerektiği emredilmiştir. Burada ki emredici kurala uyulmaması durumunda yapılan feshin geçerli fesih sonuçlarını doğurması mümkün olmayacaktır. Ancak işçinin iş sözleşmesini feshinde izlemesi gereken yol açıkça 
belirtilmediği için, fesih beyanının herhangi bir şekilde yapılması mümkündür. Yeter ki sözleşmenin feshedilmesi yönünde irade kullanıldığı ispatlanabilsin.

Kadın işçilerin evlilik nedeniyle iş sözleşmelerini feshederken hak kaybına uğramamaları için mümkün olduğunca fesih bildirimlerini yazılı veya resmi yoldan yapmaları daha yerinde olacaktır. Hatta iş sözleşmesinin feshi için gerekçe olarak evlendiklerini de belirtmeleri, bununla ilgili evlenme cüzdanı, vukuatlı nüfus kayıt örneği gibi belgelerin fotokopisinin işverene iletilmesi ispat açısından son derece yararlı görülmelidir. Ancak Yargıtay; kadın işçinin evlilik nedeniyle iş sözleşmesini sona erdirirken, işverene evlilik nedeniyle istifa ediyorum diye belirtilmese bile, istifanın evlilik tarihinden bir yıl içinde gerçekleşmiş olması halinde, kadın işçinin evlilik nedeniyle iş sözleşmesini sona erdirmiş olacağını kabul etmektedir (Kazancı, Yargıtay 7. Hukuk Dairesi. E. 2015/43996 K. 2016/11482 T. 26.5.2016). Karardan da anlaşılacağı üzere, kadın işçinin evlilik nedeniyle iş sözleşmesini feshederken, bu durumu açıkça bildirmese bile, uyuşmazlık halinde açılacak bir dava da kadın işçinin istifa ettiği tarih, evlendiği tarihten sonra ve evlilik tarihinin üzerinden bir yıl geçmeden gerçekleşmiş ise bu istifa evlilik nedeniyle iş sözleşmesini sona erdirme olarak yorumlanacak ve kadın işçilerin bu haklarını kullanabilmeleri şekil eksiklikleri nedeniyle ziyan olmayacaktır. Burada Yargıtay işçi lehine yorum ilkesini oldukça geniş olarak yorumlamıştır.

Kadın iş̧̧ilerin evlilik nedeniyle işs sözleşmelerini feshederken 4857 sayılı İ.K. m.17 de belirtilen bildirim sürelerini beklemek zorunda olup olmadıkları konusunda da bir açılık bulunmamaktadır. $\mathrm{Bu}$ fesih türünün kanunda düzenlenen bildirimli ve bildirimsiz fesih türlerine benzemediği kendine özgü bildirimsiz bir fesih türü olduğu ifade edilmektedir (Alpagut, 1998: 193). Gerçekten de kadın iş̧̧iler evlendikleri andan itibaren derhal işten uzaklaşmak isteyebilirler. $\mathrm{Bu}$ yüzden kanunda belirtilen bildirim sürelerinin beklenmesi makul bir çözüm olarak düşünülemez. Bu noktada Yargıtay; “...Kadın iş̧̧inin yasanın tanıdığı fesih hakkı kullanması nedeniyle işverene ihbar öneli tanıması zorunluluğu bulunmamaktadır..."şeklinde çözüme gitmektedir (Kazanc1, Yargitay 9. Hd. E. 2007/18608 K. 2008/14177 T. 3.6.2008). Karardan da anlaşılacağı üzere evlilik tarihinden itibaren bir yıl içinde kadın işçi, iş̧ sözleşmesini feshederken işverene sadece sözleşmeyi feshetme iradesini bildirecek ancak kanunda belirtilen bildirim sürelerini beklemeyecektir.

Kadın işçinin evlilik nedeniyle iş sözleşmesini feshedilmesi için bir yıllık süre tanınmış olması kimi durumda kadının lehine kimi durumda aleyhine olabilir. Evlenen kadın iş̧̧i bir yıl içerisinde daha iyi imkân ve şartlarda iş bulmak isteyebilir. Bunun için de çalıştığı işe devam ederken bir taraftan iş aramaya başlar. Varsayalım ki evlendiği tarihin üzerinden on ay geçince daha iyi bir iş buldu ve evlilik nedeniyle iş sözleşmesini sona erdirerek kısa bir süre sonra yeni işinde çalışmaya başladı. Bu durumda anayasal güvence altında olan çalışma hürriyeti ve kadına yüklenen toplumsal roller gereği bu şekilde işinden istifa ederek yeni işe başlaması hukuken mümkün görünmektedir. İşte bu durum kadın 


\section{Kadın İşşilerin Evlilik Nedeniyle İş Sözleşmesini Fesih Hakkı ve Sonuçları}

işçi için avantajlı bir hal oluşturmaktadır. Çünkü ortada iş sözleşmesini sona erdirebilmek için haklı bir neden yokken yeni iş bulma bahanesiyle istifa edilmiş olsa idi kadın işçinin tazminatları tehlikeye girecekti.

Kadın işçinin evlilik nedeniyle iş sözleşmesini sona erdirebileceği sürenin evlilik tarihinden itibaren bir yıl olarak düzenlenmesinin dezavantaj oluşturabilme ihtimali de bulunmaktadır. Kadın işçi evlenmiş ve evlilik nedeniyle iş sözleşmesini feshetme iradesini evliliğin onuncu ayında kullanmak isterse ve bu zaman zarfında eşinden boşanır yahut eşi vefat eder, yani evlilik sona ererse evlilik nedeniyle iş sözleşmesini feshetme hakkına sahip olmuş olabilecek midir? $\mathrm{Bu}$ durum kadın iş̧̧i açısından hakkın kullanılması hususunda dezavantaj oluşturabilir. Bu noktada iş sözleşmesinin fesih hakkı kullanılmadan sona eren evlilik nedeniyle kadın işçinin iş sözleşmesini sona erdiremeyeceği ifade edilmiştir (Narmanlıoğlu, 2014: 578). Ancak kadın işçilere evlilik nedeniyle iş sözleşmelerini haklı şekilde sona erdirebilme imkânları kanunda sadece evlilik olgusuna bağlı kılınmıştır. Yani kadın işçinin evlendiği tarihten itibaren iş sözleşmesini sona erdirebilmesi için bir yıllık süresi vardır. Kanunda belirtilen süre dolmadan kadın işçinin bu hakkını kullanabilmesi mümkün olmalıdır. Çünkü kanunda kadın işçinin bu hakkını kullanabilmesi evliliğin devam ediyor olması şartına bağlanmamıştır. Dolayısı ile evlilik tarihinden itibaren bir yıllık süre içinde iş sözleşmesini evlilik nedeniyle fesheden kadın işçinin evliliğinin devam edip etmediğine göre fesih hakkı var ya da yok diye sonuca ulaşmak kanunun kadın işçilere verdiği yetkiyi kısıtlamak olarak değerlendirilebilecektir.

\section{4. İş Sözleşmesinin Feshinin Hukuki Sonuçları}

\section{1.Çalışma Belgesinin Verilmesi}

4857 sayılı İ.K.m.28 de; İşten ayrılan işçiye, işveren tarafından işinin çeşidinin ne olduğunu ve süresini gösteren bir belge verileceği hükme bağlanmıştır. Evlilik nedeniyle iş sözleşmesini sona erdiren kadın işçinin madde de belirtilen çalışma belgesini alması, ileride başka bir işe girerken daha önce hangi türden işte ya da işlerde çalıştığını ispatlamak açısından son derece yararlı olacaktır. Günümüzde sigortalıların primleri Sosyal Güvenlik Kurumuna bildirilirken çalıştıkları işlere dair belirtilen kodlarla primleri yatırılmaktadır. Ancak bazı durumlarda SGK kodları tam olarak yapılan işi karşılamıyor ya da işçi açısından çalıştığı işin daha detaylı belgesinin alınması istenmiş olabilir. Kanunun emredici hükmü karşısında, işveren işçiye bu belgeyi vermek zorundadır. Hatta bu belgenin işçinin talebi olmaksızın verilmesi gerektiği belirtilmiştir (Aktay, 2009: 225).

Çalışma belgesinin hiç ya da vaktinde verilmemesi nedeniyle zarara uğrayan işçilerin, işverenden tazminat isteyebilecekleri de yine aynı kanun maddesinde belirtilmiştir. Bu sebeple de kadın işçiler açısından çalışma belgesi almak, işverenler açısından da bu belgeyi tam ve eksiksiz olarak, iş sözleşmesi sona erme anında derhal hazırlanıp verilmesi iki taraf açısından da olumsuz sonuçların önüne geçmeye yarayacaktır. 


\subsection{Yeni İ̧ Arama İzni}

İş sözleşmesini sona erdirecek kadın işçinin, bir daha iş hayatında bulunmama kararı aldığını düşünmek çoğu durumda doğru bir yaklaşım olmayacaktır. Bu gibi haller 4857 sayılı İ.K. da önceden düşünülerek, iş sözleşmesini sona erdirme niyetinde olan işçilere, yeni iş arama izni verilmesi gerektiği belirtilmiştir. İ.K. m.27: "Bildirim süreleri içinde işveren, işçiye yeni bir iş bulması için gerekli olan iş arama iznini iş saatleri içinde ve ücret kesintisi yapmadan vermeye mecburdur..." hükmü sevk edilmiştir. Kanunun düzenleniş şekli irdelendiğinde, yeni iş arama izninden yararlanabilmek için, iş sözleşmesinin bildirimli fesih yoluyla sona erdirilmesi gerektiği sonucuna ulaşılmaktadır. İş sözleşmesinin derhal feshini gerektiren durumlarda, işçi ile işveren arasındaki ilişki anında sona ereceği için iş̧̧inin iş arama izni kullanabilmesi mümkün olmayacaktır.

Kadın işçilerin evlilik nedeniyle iş sözleşmelerini sona erdirebilmeleri için yukarıda verilen Yargıtay kararları ile de bildirim süresinin beklenmesinin gerekli olmadığı sonucuna ulaşılmıştır. Bu sebeple, kadın işçinin evlilik nedeniyle iş sözleşmesini derhal sona erdireceğinin kabulü ile bu halde kadın işçiye yeni iş arama izni verilmesi de mümkün görünmemektedir.

\subsection{Yeni İsverenin Sorumluluğu}

Hukuki ilişkiler güven duygusu üzerine kurulurlar. $\mathrm{Bu}$ olgunun iş hukukunda daha derinden hissedilmesi gerekmektedir. İşveren işe aldığ 1 işçisine bir nevi mahremini açmakta ve özellikle büyük üretim faaliyetlerinin gerçekleştirildiği işyerlerinde iş sırrı kavramı daha fazla önem arz etmektedir. Bu sebeple işçinin işvereni yüzüstü bırakması, ya da başka bir işveren tarafından çalıştığ 1 işi bırakıp kendi işyerinde yeni işe başlaması yönünde telkinde bulunması mümkün olabilmektedir. Bu gibi durumlarda iyiniyetli işverenin korunması gerekliliği ortaya çıkacaktır. İște bu nedenle 4857 sayılı İ.K.m.23 ile; "Süresi belirli olan veya olmayan sürekli iş sözleşmesi ile bir işverenin işine girmiş olan işçi, sözleşme süresinin bitmesinden önce yahut bildirim süresine uymaksızın işini bırakıp başka bir işverenin işine girerse sözleşmenin bu suretle feshinden ötürü, işçinin sorumluluğu yanında, ayrıca yeni işveren de aşağıdaki hallerde birlikte sorumludur:

a) İşçinin bu davranışına, yeni işe girdiği işveren sebep olmuşsa,

b) Yeni işveren, işçinin bu davranışını bilerek onu işe almışsa,

c) Yeni işveren işçinin bu davranışını öğrendikten sonra dahi onu çalıştırmaya devam ederse".

Kadın işçinin evlilik nedeniyle iş sözleşmesini sona erdirip, başka bir işverenin yanında işe başlaması durumunda, kanunda sayılan bu durumların hiçbirisi gerçekleşmiş olmayacaktır. Burada iş sözleşmesini sona erdirme nedeni olarak "evlilik" gösterilmektedir. Kaldı ki kadın işçinin bu hakkını kullanırken bildirim sürelerine uymak zorunda olmadığı da göz önüne alındığında, yeni işverenin sorumluluğu yoluna gitmek mümkün olmayacaktır. Kadın işçinin iş 


\section{Kadın İşşilerin Evlilik Nedeniyle İş Sözleşmesini Fesih Hakkı ve Sonuçları}

sözleşmesini evlilik nedeniyle feshetmesine yeni işveren sebep olsa dahi, kadın işçinin iş sözleşmesini evlilik nedeniyle feshettikten sonra yeni işveren bu durumu bilerek kadın işçiyi işe alsa ve son olarak bu durumu öğrendikten sonra kadın iş̧̧iyi çalıştırmaya devam etmiş olsa bile, yeni işverenin sorumluluğundan söz etmek olanaksızdır.

\subsection{Rekabet Yasă̆}

İşçi, işini gördüğü işverenin üretim sırları, müşteri çevresi, portföyü vb. unsurlara rahatlıkla erişebilmektedir. İşveren açısından mahrem nitelikteki bu bilgilerin kullanılması pekâlâ mümkün görülebilecektir. Bu nedenle işverenin, sırf yanında çalıştırdığı işçinin kötü niyetli davranışı nedeniyle zarara uğramasının önüne geçilebilmesi için işçinin iş sözleşmesinin sona ermesiyle, eski işvereniyle rekabet etmesinin yasaklanması mümkündür. İş hukukunda işçi tarafin rekabet yasağı mutlak bir durum olmayıp taraflar bunu sözleşme ile kararlaştırmalıdır (Manav, 2010: 323).

Rekabet yasağına yönelik iş hukukunda düzenleme bulunmamaktadır. Konu 6098 sayılı Türk Borçlar Kanununun 444-447 maddelerinde düzenlenmiştir. İlgili düzenlemeler irdelendiğinde ilk olarak; işçinin, işverene karşı, sözleşmenin sona ermesinden sonra herhangi bir biçimde onunla rekabet etmekten kaçınmayı yazılı olarak üstlenebileceği görülmektedir. Buradan da anlaşılacağı üzere rekabet yasağı her iş sözleşmesi ile bütün halde ortaya çıkan bir durum değildir. İşçinin rekabet etmeme yönünde yazılı bir sözleşme yapması ya da iş sözleşmesinde böyle bir maddenin belirlenmiş olması gerekmektedir (Süzek, 2014: 464). Aksi takdirde rekabet yasağından söz edilemeyecektir.

TBK' da rekabet yasağı çok sıkı şekil şartlarına tabi tutulmuştur. İki tarafinda menfaati korunmaya, denge gözetilmeye çalışılmıştır. Ne çok katı olarak işçiyi ekonomik zorluğa düşürmeyi, ne de işverenin tüm sırlarının ortaya çıkmasının istenmediği sınırlamalar görülmektedir.

Kadın iş̧̧inin evlilik nedeniyle iş sözleşmesini sona erdirmesi halinde rekabet yasağının söz konusu olup olmadığı, her olayın kendi içinde çözülmesi gereken bir hal olarak karşımıza çıkmaktadır. Kadın işçinin, işverenle yaptığı iş sözleşmesinde ya da sonradan yaptıkları bir sözleşme de işverenle rekabet etmesini engelleyici düzenlemelere rastlamak mümkün olabilir. Bu yasak TBK gereği; kendi hesabına rakip bir işletme açmayı, başka bir rakip işletmede çalışmayı veya bunların dışında, rakip işletmeyle başka türden bir menfaat ilişkisine girişmekten kaçınmayı kapsamaktadır.

İlgili düzenlemeler birlikte değerlendirildiğinde; kadın işçinin evlilik nedeniyle iş sözleşmesini sona erdirmesi durumunda, işveren ile arasında yazılı rekabet yasağı kaydı mevcut ise bu yasağa uyulması gerektiği, bu yönde bir anlaşma mevcut değilse kadın işçinin yeni iş hayatında bir takım yasaklarla karşılaşmasının olanaksız olduğu sonucuna ulaşılabilecektir.

\subsection{Ibraname}


Kelime anlamı olarak aklama, temize çıkarma manalarına gelen ibra, borçlar hukuku bağlamında da borçlusunda bulunan alacağından tamamen veya kısmen vazgeçme olarak tanımlanmaktadır (Çil, 2007: 1-2; Önen, 1999: 229; Kılıçoğlu, 2012: 820).

İbra konusu da rekabet yasağ gibi iş mevzuatında düzenlenen bir konu değildir. Yine konu ile ilgili TBK düzenlemeleri bulunmaktadır. TBK $131 \mathrm{vd.}$ maddelerinde borçların sona erme hallerini düzenlemiştir. 132.ci madde ile herhangi bir sözleşmenin taraflarının, aralarında yapacakları ibra sözleşmesi ile borcu tamamen veya kısmen ortadan kaldırılabilecekleri düzenlenmiştir. Buradan da anlaşılacağı üzere ibra bir borcu kısmen veya tamamen sona erdiren hallerdendir.

TBK 420.ci maddesinde işçi ile işveren arasında yapılacak ibra sözleşmesinin nasıl yapılması gerektiği ve ibranamenin geçerlilik koşulları belirtilmiştir. İlk olarak işçi ile işveren arasında yapılacak ibra sözleşmesinin mutlaka yazılı yapılması gerektiği belirtilmiştir. İş iliş̧isinin devamı sırasında ibra sözleşmesinin yapılmasına müsaade edilmemiş, ibra sözleşmesinin iş ilişkisinin sona erme tarihinden en az bir ay geçmiş olması şartına bağlanmıştır. Bu bir aylık süre çok önemlidir. Çünkü iş ilişkisi devam ederken işçi, işverenden duyduğu endişeler nedeniyle üzerinde oluşan baskıdan ötürü ibra sözleşmesi imzalayabilmektedir (Kazanc1, Yargitay. 9. HD. E. 2009/4140 K. 2011/3924 T. 18.2.2011). Dolayısı ile kanun bunun önüne geçmiştir. Yine ibra konusu alacağın türünün ve miktarının ibra sözleşmesinde açıkça belirtilmesi ve işveren tarafindan yapılacak ödemenin banka aracılığıyla yapılması zorunlu kılınmıştır. $\mathrm{Bu}$ şartları taşımayan ibra sözleşmeleri kesin hükümsüz sayılmıştır.

Kadın işçinin evlilik nedeniyle iş sözleşmesini sona erdirirken işverenden alacaklarını tam ve eksiksiz olarak alması gerekmektedir. Aralarında hukuki bir ilişki kalmayarak, tarafların birbirlerine karşı olan alacak ve borçlarını yerine getirmiş olmaları gerekmektedir. Kadın işçinin, işverenden olan alacaklarını alarak ibra sözleşmesi yapması ve bu sözleşmenin geçerli olmasına ilişkin yukarıdaki açıklamalar aynen geçerli olacaktır. İbra sözleşmelerinin düzenleniş ve geçerlilik şartları bakımından işçi lehine düzenlemeler içerdiği görülmektedir. Özellikle iş sözleşmesinin sona ermesinden itibaren en az bir aylık süre geçmeden bu sözleşmenin yapılamayacağı ve ödemenin bankadan yapılması gerekliliği, alacaklarına kavuşmayan işçinin işvereni ibra etmesinin önüne geçmekte ve işçinin haklarına halel getirmemektedir.

\subsection{Kıdem Tazminatı}

Kıdem tazminatı değişik şekillerde tanımlanmaktadır. Bunlardan bazıları; işçinin gördüğü iş nedeniyle yıpranmasının parasal karşıllı̆̆ (Anadolu, 2003: 10), işten çıktığ 1 için karşılaşacağı ekonomik sorunları bir süre de hafifletmek için ödenen toplu para (Işıkl1, 2002: 93), ileriye bırakılmış ücret(Işıklı, 2002: 93) alacağ1 şeklindedir. Öğretide kıdem tazminatı tanımı üzerinde görüş birliği olmamakla birlikte, iş̧̧inin kanunun öngördüğü şekilde iş sözleşmesinin sona 


\section{Kadın İşşilerin Evlilik Nedeniyle İş Sözleşmesini Fesih Hakkı ve Sonuçları}

ermesine istinaden, işverenden alması gereken parasal değer olarak ifade edilebilmektedir.

Kıdem tazminatı konusu 1475 sayılı eski İ.K.'da düzenlenmiş olup kıdem tazminatı fonu kurulması öngörüldüğü için günümüzde yürürlükte bulunan 4857 sayı1ı İș Kanunu'nda kıdem tazminatı düzenlemesi bulunmamaktadır. 2004 yılında yürürlüğe giren yeni İ.K.'nın öngördüğü kıdem tazminatı fonu halen kurulamamış olup, fon tartışmaları güncelliğini korumaktadır. Dolayısı ile kıdem tazminatı fonu kurulana kadar, 1475 sayılı İ.K.' da ki kıdem tazminatına ilişkin düzenlemeler yürürlüktedir.

1475 sayılı İ.K. m.14 de hangi hallerde kıdem tazminatına hak kazanılacağ 1 belirtilmiştir. Konumuz ile ilgili olan düzenleme, kadının evlendiği tarihten itibaren bir yıl içerisinde kendi arzusu ile iş sözleşmesini sona erdirmesi halinde kıdem tazminatına hak kazanacağıdır. Düzenlemeden de anlaşılacağı üzere kadın iş̧̧inin evlilik tarihinden itibaren bir yıl içinde iş sözleşmesini sırf evlilik nedenine dayanarak kendi arzusu ile sona erdirmesi halinde kıdem tazminatına hak kazanacağı sonucuna ulaşılacaktır.

Kıdem tazminatının nasıl hesaplanması gerektiği yine aynı kanun maddesinde açıklanmıştır. İlgili düzenleme; “...iş̧̧inin işe başladığı tarihten itibaren hizmet akdinin devamı süresince her geçen tam yıl için işverence işçiye 30 günlük ücreti tutarında kıdem tazminatı ödenir. Bir yıldan artan süreler için de aynı oran üzerinden ödeme yapılır" şeklindedir. Yani iş̧̧inin bir yıllık çalışmaları işçinin otuz günlük ücreti üzerinden tazminat hesaplanmasını gerektirmektedir. Yine kanun gereği işçinin bir yılı tamamladıktan sonraki çalışma süreleri içinde çalıştı̆̆ sürenin bir yıla oranına göre tazminat almas1 gerektiği belirtilmiştir. Örneğin iş̧̧i bir yıl dört ay çalıştıktan sonra evlilik nedeniyle iş sözleşmesini sona erdirecek olursa, bir tam yıl için otuz günlük ücreti, dört aylık çalışması içinde on günlük ücreti yani toplamda kırk günlük ücretinin kıdem tazminatı olarak hesaplanmas1 gerekecektir.

İşçilerin kıdem tazminatlarına hak kazanmaları bakımından bir yıllık sürenin hesaplanması kanunda ayrıntılı olarak açıklanmıştır. "işçilerin kıdemleri, hizmet akdinin devam etmiş veya fasılalarla yeniden akdedilmiş olmasına bakılmaksızın aynı işverenin bir veya değişik işyerlerinde çalıştıkları süreler göz önüne alınarak hesaplanır. İşyerlerinin devir veya intikali yahut herhangi bir suretle bir işverenden başka bir işverene geçmesi veya başka bir yere nakli halinde iş̧̧inin kıdemi, işyeri veya işyerlerindeki hizmet akitleri sürelerinin toplamı üzerinden hesaplanır". İlgili düzenlemeden de anlaşılacağı üzere işverenlerin işçilerine kıdem tazminatı ödememek için sigorta kayıtlarında giriş çıkış yapmış olmaları halinde bile aynı işverene bağlı fasılalı çalışma durumunun gerçekleşmiş olacağı kabul edilmiş ve işçilerin hak kayıplarının önüne geçilmiştir.

Kıdem tazminatı yasada işçinin her tam yıllık çalışmasına karşılık otuz günlük ücreti olarak öngörülmüş olup, tazminat hesaplamasının işçinin aldığı son ücret üzerinden yapılacağı belirtilmiştir. Kıdem tazminatına esas hesaplamada 
işçinin son ücretinin net eline geçen ücret mi, brüt ücret mi yoksa giydirilmiş ücret mi olacağı yönünde kanunda bir açıklık bulunmamaktadır. Yargıtay bu noktada yerleşik olarak kıdem tazminatı hesaplanırken işçinin giydirilmiş ücreti üzerinden hesaplanması gerektiğini belirterek, giydirilmiş ücreti de nakdi ve nakdi olmayan değerler bütünü olarak ifade etmektedir(Kazancı, Yargıtay Hukuk Genel Kurulu E. 2016/22-2083 K. 2019/867 T. 4.7.2019; Yargitay Hukuk Genel Kurulu E. 2017/22-2948 K. 2019/705 T. 18.6.2019).

Kıdem tazminatı miktarının işçi lehine artırılabilmesine kanun olanak tanımıştır. Ancak bununla ilgili bir üst sınır belirlenmiştir. Bu sınır en yüksek devlet memuru kabul edilen memura bir yıllık çalışmasına karşılık ödenecek azami emekli ikramiyesi miktarı olarak tayin edilmiştir. Kıdem tazminatı miktarının iş sözleşmesi veya toplu iş sözleşmeleri ile artırılabilmesi kanunun cevaz verdiği ve işçi lehine düzenleme olarak karşımıza çıkmaktadır. Her ne kadar işçi lehine düzenleme olarak düşünülse de burada tamamen keyfi olarak kıdem tazminatı miktarı belirlenmesinin de önüne geçilmiştir.

\section{7.İhbar Tazminatı}

4857 say1l İ.K. m.17 de süreli fesih konusu düzenlenmiştir. Süreli fesih, iş sözleşmesini feshedecek tarafın, işçinin işyerindeki çalışma süresine göre kanunda belirtilen süre kadar önceden bu durumu karşı tarafa bildirmesi gerekliliğidir. Gerek işçi gerekse de işveren tarafından iş sözleşmesinin feshedilecek olması bu durumu farklılaştırmamaktadır. Her iki tarafta fesih için burada belirtilen sürelere uymak zorundadır. Aksi takdirde bu sürelere uymayan taraf diğer tarafa ihbar tazminatı adı verilen bu tazminatı ödemek durumunda kalacaktır. İhbar tazminatı açısından en önemli nokta, iş sözleşmesinin feshi için gerekli bildirimin kanunun koyduğu süre içinde yapılmaması halinde işçinin de işverene bu tazminatı ödemek zorunda kalabileceğidir (Bozkurt, 2001: 793).

İhbar tazminatı konusunda işverenin, ihbar sürelerini beklemeksizin peşin ücret ödeyerek işçi ile iş sözleşmesini sona erdirebilmesi mümkün kılınmıştır. $\mathrm{Bu}$ hak işçilere tanınmamıştır. Yani iş sözleşmesini bildirimli olarak feshedecek işçinin, kıdemine göre kanunun aradığı süreleri beklemek zorunda olduğu kuşkusuzdur.

Kadın işçinin evlilik nedeniyle iş sözleşmesini kendi iradesi ile sona erdirmesi, istifa etmesi anlamına gelmektedir. Yargitay kararlarında da belirtildiği üzere istifa eden işçinin ihbar tazminatı talep edebilmesi mümkün değildir(Kazanc1, Yargıtay 9. Hukuk Dairesi E. 2015/16611 K. 2015/22341 T. 18.6.2015, Yargitay 7. Hukuk Dairesi E. 2013/26197 K. 2014/4282 T. 13.2.2014).

İlgili kanunun 17.ci maddesinde belirsiz süreli iş sözleşmelerinin feshinden önce durumun diğer tarafa bildirilmesi gerekeceği belirtilmiştir. Kadın işçinin belirsiz süreli iş sözleşmesi ile çalışması halinde evlilik nedeniyle iş sözleşmesini feshederken kanunun öngördüğü süreleri beklemesi gerekmeyecektir (Kazanc1, Yargitay 9. Hukuk Dairesi E. 2007/18608 K. 2008/14177 T. 3.6.2008). 


\section{Sonuç}

Kadın işçilerin evlilik nedeniyle kendi iradeleri doğrultusunda iş sözleşmelerini feshedebilmeleri ve bu yönüyle de kıdem tazminatına hak kazanabilmeleri ilk bakışta kadın işçiler açısından olumlu bir düzenleme gibi görülebilir. İlgili düzenleme yürürlükten kaldırılan 1475 sayılı İş Kanunu' nda yer alan bir madde olarak günümüzde geçerliliğini korumaktadır. Bu kanun 1971 yılında çıkarılmış olup, 2003 yılında 4857 sayılı İş Kanunu ile yürürlükten kaldırılmıștır.

Eski kanun döneminin şartları ve kadının toplumdaki rolü ile yasal düzenlemeler göz önüne alındığında, kadın işçilerin evlendiklerinde işgücü piyasasından çekilmeleri kolaylaştırılmak ve kıdem tazminatı gibi konularla da teşvik edilmek istenmiştir. Ülkemizde 1926 yılında kabul edilen 743 sayılı Türk Kanunu Medenisi'ne göre kadın erkek eşitliğinden söz etmek mümkün değildir. İlgili kanun 159.cu maddesinde kadının bir işte çalışmasını kocasının müsaadesine tabi kılmıştır. Bahsedilen kanun 2001 yılına kadar yürürlükte kalmıştır. Dolayısı ile cumhuriyetin ilk yıllarından 2000li yıllara kadar kadının çalışma hayatında ki yeri geri planda kalmıştır.

Kadınların çalışabilmeleri için kocalarından izin almasına yönelik düzenlemenin, iş hukukunda ki karşılığ $\mathrm{da}$, evlenen kadının aslında kocasının iznini alarak işine devam edip etmeyeceği yönünde iradesini ortaya koyabilmesi arzusudur. Gerçekten de eski Medeni Kanun ve kadın işçinin evlilik nedeniyle iş sözleşmesini feshedebilme hakkı birlikte değerlendirildiğinde, evlenen kadına kocasının çalışma izni verip vermeyeceğini belirleme imkânı vermektedir. $\mathrm{Bu}$ yönüyle de velev ki koca karısının çalışmasına izin vermez ise kadın iş̧̧inin evlilik tarihinden itibaren bir yıl içinde iş sözleşmesini sona erdirebilmesine olanak sağlanmıştır.

Yürürlükte bulunan Medeni Kanun ile kadınların iş hayatına girmeleri ve devam edebilmeleri için gerek eşlerinden gerekse başka bir yerden izin almaları gerekliliği kabul edilmemiştir. Bu yönüyle medeni hayatta kadın erkek eşitliğine bir eğilim olsa da iş hayatı bakımından kadın işçinin evlilik nedeniyle iş sözleşmesini sona erdirebilme hakkı yine de kadınlara evlenirseniz işi bıraksanız daha iyi olur imajı vermektedir. Ancak, sosyal politika açısında dezavantajlı grup içerisinde yer alan kadınların korunması esas alınmalıdır. Çalışan kadının evlenmesi durumunda ilk bir yıl içerisinde daha esnek çalışabileceği başka bir iş bulduğu zaman rahatlıkla geçebilmesi, kadın işgücünün piyasadan uzaklaşmamasını sağlayacak bir kolaylığı da beraberinde getirmektedir. Evlilik tüm toplumlarda korunması gereken bir kavram olarak görüldügü için kadınlara verilen bu hakkın erkeklere de verilmesi bir öneri olarak sunulmaktadır. Her iki cinsiyete böyle bir hak verildiğinde, işverenler kadınlara yönelik bir ayrıma başvuramayacaklardır.

Yasal düzenlemenin bu haliyle yürürlükte kalacağını düşünecek olursak, düzenlemenin yetersiz olduğunu belirtmekte fayda vardır. Yasa da kadın işçilerin evlilik nedeniyle iş sözleşmelerini evlilik tarihinden itibaren bir yıl içinde sona 
erdirebilecekleri belirtilmektedir. Ancak eski eşle yeniden evlenerek ya da başkaca bir şekilde hakkın kötüye kullanılmasının önüne geçecek düzenlemeler yapmak gerekmektedir. Hatta evlilik tarihinden itibaren bir yıl dolmadan boşanılması ya da ölüm gibi nedenle evliliğin sona ermesi durumunda kadın işçinin yine de iş sözleşmesini sona erdirip erdiremeyeceğinin de yasal düzenlemeye kavuşması gerekmektedir. Son olarak, kadın işçinin evlilik nedeniyle iş sözleşmesini feshederken, bu feshin süreli fesih değil, derhal fesih hali oluşturacağının belirtilmesi faydalı olacaktır.

\section{Kaynaklar}

Aktay, A.N., Arıcı, K., Ve Senyen K, E.T. (2009), İ̧ Hukuku, Ankara: Seçkin Yayınc1lik.

Alp, M. (2003), İşçinin Feshe Karşı Korunması 'İş Güvencesi Yasası', Dokuz Eylül Üniversitesi Hukuk Fakültesi Dergisi, 5 (1), 1-40.

Alpagut, G. (1998), Belirli Süreli Hizmet Sözleşmesi, Ankara: Konuk Kitabevi.

Anadolu, F.K. (2003), Kıdem Tazminatı Koşulları Ve İşçinin Kıdeminin Hesaplanması, Selçuk Üniversitesi Sosyal Bilimler Enstitüsü Dergisi,10, 239-264.

Bozkurt, H.A. (2001), Işs Davaları, Ankara: Adil Yayınevi.

Centel, T. (2009), Kıdem Tazminatında Pozitif Ayrımcılık, Sicil İşs Hukuku Dergisi, 15, 5-10.

Çelik, N., Caniklioğlu, N., ve Canbolat, T. (2015), Işs Hukuku Dersleri, İstanbul: Beta Yayınları.

Çil, Ş. (2007). İ̧̧ Hukukunda İbra Sözleşmesi, İstanbul: Legal Yayınc1lık.

Esener, T. (1978), $\dot{I}_{s ̧}$ Hukuku, Ankara: Ankara Üniversitesi Hukuk Fakültesi Yayınları.

Günay, C. İ. (2010), İş Güvencesi Uygulamasında Hukuki Sorunlar Ve Öneriler, Osman Güven Çankaya'ya Armağan, Ankara: Kamu İşletmeleri İşverenleri Sendikası.

Iş1klı, A. (2002). İ̧s Hukuku, Ankara: İmaj Yayınevi.

Kaplan, E. T. (1987), İşverenin Fesih Hakkı Sinırları, Hüküm Ve Sonuçları, Ankara: Kadığlu Matbaası.

Kılıçoğlu, A. (2012), Borçlar Hukuku Genel Hükümler, Yeni Borçlar Kanunu'na Göre Hazırlanmış 15. Basım, Ankara: Turhan Yayınevi.

Manav, A. E. (2010), İş Hukukunda Rekabet Yasağı Sözleşmesinin Geçerlilik Koşulları, TBB Dergisi, 87, 322-364.

Mollamahmutoğlu, H., Astarlı, M., Ve Baysal, U. (2014), İş Hukuku, Ankara: Turhan Kitabevi.

Narmanlığlu, Ü. (2014), İ̧s Hukuku Ferdi İş İlişkileri I, İstanbul: Beta Yayınları. Oğuzman, K. (1955), Türk Borçlar Kanunu Ve Işs Mevzuatına Göre Hizmet 'İ̧s' Akdinin Feshi, İstanbul: İstanbul Akgün Matbaası.

Önen, T. (1999), Borçlar Hukuku Genel Hükümler, Ankara: Yarg1 Yayınevi.

Sümer, H. H. (2015), İ̧ Hukuku, Konya: Mimoza Yayınları, 
Süzek, S. (2014), Yeni Türk Borçlar Kanunu Çerçevesinde İşçinin Rekabet Etmeme Borcu, İstanbul Üniversitesi Hukuk Fakültesi Mecmuası,72 (2), 457-467.

Süzek, S. (2015), Işs Hukuku, İstanbul: Beta Yayınları.

Şakar, M. (2019), Meslek Yüksekokulları İçin İş Hukuku Ve Sosyal Güvenlik Hukuku, İstanbul: Beta Yayınları.

Yargitay 9. Hd. E. 2007/18608 K. 2008/14177 T. 3.6.2008, Yargitay 9. Hd. E. 2012/10999 K. 2014/16076 T. 20.5.2014, 10.02.2020 tarihinde www.kazanc1.com adresinden alınd1.

Yargitay 9. Hukuk Dairesi. E. 2012/10999 K. 2014/16076 T. 20.5.2014, 10.02.2020 tarihinde www.kazanc1.com adresinden alınd1.

Yargitay 9. Hukuk Dairesi E. 2012/10999 K. 2014/16076 T. 20.5.2014, 10.02.2020 tarihinde www.kazanc1.com adresinden alındı.

Yargitay 22. Hukuk Dairesi E. 2017/10878 K. 2018/5005 T.27.2.2018, 10.02.2020 tarihinde www.kazancı.com adresinden alındı.

Yargitay 9. Hukuk Dairesi E. 2014/17600 K. 2015/30741 T. 2.11.2015, 10.02.2020 tarihinde www.kazanci.com adresinden alınd1.

Yargitay 7. Hukuk Dairesi. E. 2015/43996 K. 2016/11482 T. 26.5.2016, 10.02.2020 tarihinde www.kazanc1.com adresinden alındı.

Yargitay 9. Hukuk Dairesi. E. 2007/18608 K. 2008/14177 T. 3.6.2008, 10.02.2020 tarihinde www.kazanc1.com adresinden alındı.

Yarg. 9. Hukuk Dairesi. E. 2009/4140 K. 2011/3924 T. 18.2.2011, 04.02.2020 tarihinde www.kazanc1.com adresinden alınd1

Yargitay Hukuk Genel Kurulu E. 2016/22-2083 K. 2019/867 T. 4.7.2019, Yargitay Hukuk Genel Kurulu E. 2017/22-2948 K. 2019/705 T. 18.6.2019, 10.02.2020 tarihinde www.kazanc1.com adresinden alındı.

Yargitay 9. Hukuk Dairesi E. 2015/16611 K. 2015/22341 T. 18.6.2015, Yargitay 7. Hukuk Dairesi E. 2013/26197 K. 2014/4282 T. 13.2.2014,09.02.2020 tarihinde www.kazanci.com adresinden alınd.

Yargitay 9. Hukuk Dairesi E. 2015/16611 K. 2015/22341 T. 18.6.2015, Yargitay 7. Hukuk Dairesi E. 2013/26197 K. 2014/4282 T. 13.2.2014, 10.02.2020 tarihinde www.kazanc1.com adresinden alınd1.

Yargitay 9. Hukuk Dairesi E. 2007/18608 K. 2008/14177 T. 3.6.2008, 10.02.2020 tarihinde www.kazanc1.com adresinden alınd1. 